\title{
A novel consensus bacterial 6-phytase variant added to phytate-rich diets totally replaced inorganic phosphate in broilers
}

\author{
Y. Dersjant-Li ${ }^{1 *}$, A. Bello ${ }^{1}$, E. Esteve-Garcia ${ }^{2}$, C. Ramírez Creus ${ }^{2}$ and L. Marchal ${ }^{1,3}$ \\ ${ }^{1}$ Danisco Animal Nutrition \& Health, IFF, Willem Einthovenstraat 4, 2342 BH Oegstgeest, the Netherlands; ${ }^{2}$ IRTA, Animal \\ Nutrition, Centre Mas Bové, 43120 Constantí, Spain; ${ }^{3}$ Animal Nutrition Group, Wageningen University E Research, \\ De Elst 1, 6708 WD Wageningen, the Netherlands; yueming.dersjant-li@iff.com
}

Received: 6 September 2021 / Accepted: 31 January 2022

(c) 2022 Y. Dersjant-Li

RESEARCH ARTICLE

POULTRY

\begin{abstract}
The capacity of a novel bacterial 6-phytase variant (PhyG) to totally replace dietary supplemental inorganic phosphate (Pi) in broilers aged one day old was evaluated using a phased dosing strategy and reduction in dietary phytate. A total of 1,248 one-day-old Ross 308 broilers were assigned to 24 pens (52 birds/pen, 12 pens/diet, six each males and females) in a complete randomised block design with a $2 \times 2$ factorial arrangement (two diets, two genders). Diets comprised: (1) a positive control (PC) based on maize, wheat and soybean meal, containing Pi from monocalcium phosphate and 2,000 XU/kg xylanase, and; (2) an inorganic phosphate-free (IPF) diet equivalent to PC but with reduced $\mathrm{Ca}(-2.0 \mathrm{~g} / \mathrm{kg})$ and supplemented with PhyG at 3,000, 2,000 and $1000 \mathrm{FTU} / \mathrm{kg}$ from d 0 to $11(3.4 \mathrm{~g} / \mathrm{kg}$ phytate-P (PP)), d 11 to $22(3.3 \mathrm{~g} / \mathrm{kg} \mathrm{PP})$ and d 22 to $42(2.8$ to $2.9 \mathrm{~g} / \mathrm{kg} \mathrm{PP})$, respectively. A negative control was not included for animal welfare reasons. Tibias were collected on d 11, 22 and 42 from two birds/pen. Treatment IPF maintained or improved average daily gain (ADG), average daily feed intake and feed conversion ratio (FCR) vs PC during all phases; Body weight was higher in the IPF treatment than the $\mathrm{PC}$ at $\mathrm{d} 42(+3.97 \%, P<0.01)$ and ADG during $\mathrm{d} 0$ to $42(+4.10 \%, P<0.01)$. Overall (d 0 to 42$)$, treatment IPF improved FCR in males $(-5$ points vs PC, $P<0.05)$ but not females. Tibia ash was equivalent in IPF and PC throughout, with no gender differences. In conclusion, when applied as a phased dosing strategy to diets with graded reduction in PP content, PhyG totally replaced supplemental Pi during all growth phases in males and females.
\end{abstract}

Keywords: phosphorus, phytase, phytate, poultry

\section{Introduction}

To ensure phosphorus $(\mathrm{P})$ requirements are met, inorganic phosphate $(\mathrm{Pi})$ is routinely added to poultry feed, often in the form of mono- or di-calcium phosphate (MCP or DCP) which are manufactured from naturally occurring phosphate rock. However, phosphate rock is a finite resource and there is high global demand for inorganic phosphates. As a result, costs remain high (Markets and Markets, 2018). If dietary $P$ is in excess of bird requirements, it is excreted, which can have negative environmental consequences (Sharply et al., 1994). There is therefore a need to develop more sustainable production practices that do not require Pi to be added to the diet.
Microbial phytase supplementation is one potential approach to achieving this. Phytase hydrolyses phytate (the salt of phytic acid, myo-inositol hexaphosphate; $\mathrm{IP}_{6}$ ) in plant-based ingredients (Selle and Ravindran, 2007), releasing $\mathrm{P}$ in the form of phosphate that can be utilised by the bird, thereby reducing the amount of undigested $\mathrm{P}$ that is excreted. The efficacy of microbial phytase for increasing the bioavailability of $\mathrm{P}$ in broiler diets is well recognised (Lei et al., 2013; Selle and Ravindran, 2007) and it is commonly used in commercial broiler diets.

Matrix values prescribing the nutrient reductions that may be applied to the diet in conjunction with the use of a given 
phytase have enabled a reduction in the amount of $\mathrm{Pi}$ (and other nutrients) that needs to be added to broiler diets, but total Pi-replacement by phytase is a more novel concept. A limited number of previous studies (Ribiero et al., 2019; Scholey et al., 2018) have reported total replacement of Pi by a phytase in broiler diets during grower and/or finisher phases, but not during the starter phase. Total replacement of Pi during this phase is a particular challenge because of the high requirement of young birds (available $\mathrm{P}(\mathrm{AvP})$ at $4.8 \mathrm{~g} / \mathrm{kg}$ of the diet during 0 to $10 \mathrm{~d}$ of age, Aviagen Inc., 2019a) which is necessary to support a period of rapid growth and bone mineralisation. Meanwhile, when diets are formulated without $\mathrm{Pi}$, the available $\mathrm{P}$ in all vegetable-based diets with high phytate content (3.3 to $3.8 \mathrm{~g} / \mathrm{kg}$ phytate-P (PP), formulated values) is about 1.5 to $1.6 \mathrm{~g} / \mathrm{kg}$ (Marchal et al., 2021). This means that in theory, a phytase needs to release up to $\sim 3.2-3.3 \mathrm{~g} / \mathrm{kg}$ AvP from phytate in order to totally replace Pi during the starter phase.

Recently, $1000 \mathrm{FTU} / \mathrm{kg}$ of a novel consensus bacterial 6-phytase variant with high in vitro and in vivo capacity to degrade phytate (Christensen et al., 2020) was successful in replacing an estimated $2.07 \mathrm{~g}$ MCP-derived P per kilogram of diet in broilers (Dersjant-Li et al., 2020a). The phytase maintained performance and tibia ash equivalent to a nutritionally adequate diet during all growth phases (Dersjant-Li et al., 2020a). A further analysis of two separate trials showed that the same phytase applied with different dosing strategies maintained or improved growth performance and maintained tibia ash when used as a total replacement for $\mathrm{Pi}$ (Marchal et al., 2021). One of the treatments applied the phytase to nutrient-reduced diets at $1000 \mathrm{FTU} / \mathrm{kg}$ throughout all phases whereas the other employed a phased dosing-regimen which was high in starter phase $(3,000 \mathrm{FTU} / \mathrm{kg})$ and lower in finisher phase (1000 FTU/kg). In both trials, although a consistent dose of $1000 \mathrm{FTU} / \mathrm{kg}$ during all phases maintained performance compared to a positive control (PC), the phased dosing strategy improved growth performance compared to the PC (Marchal et al., 2021). In these trials, the PC was formulated without other enzymes and the basal diets were high in PP during all phases in order to ensure sufficient substrate for the phytase in diets without Pi. However, whilst high phytate is thought to be critical for phytase efficacy in the starter phase to provide sufficient substrate to meet higher digestibility needs, the lower $P$ requirement during later growth stages means that it may be possible to reduce the PP content in later phases. This is preferable on sustainability grounds, because it would allow more flexibility in the choice of feed ingredients. In addition, the two trials reported by Marchal et al. (2021) were carried out with 24 to 26 birds per pen and were carried out in males or in mixed sexes housed together. The concept of dietary Pi-replacement by phytase needs to be evaluated in large-scale studies and in males and females separately, as the different growth rates and nutrient requirements of the sexes may lead to different responses to phytase. In addition, the PC diets in the Marchal et al. (2021) trials were formulated without carbohydrase. When diets contain increased levels of phytate rich ingredients such as rapeseed meal and rice bran, xylanase is frequently added to such diets to improve the digestion of non-starch polysaccharides (NSP) (Choct and Annison, 1992).

Against this background, the following study tested the hypothesis that the novel consensus 6-phytase variant previously used in trials could allow total replacement for dietary Pi containing a graded reduction in PP by phase, in both male and female broilers.

\section{Materials and methods}

The study was conducted at the Institute of Agrifood Research and Technology (IRTA) Mas Bové Research Facility in Constantí, Spain. All experimental procedures were conducted in compliance with European Directive 2010/63/EU (European Council, 2010) and the Spanish guidelines for the care and use of animals in research (B.O.E. number 252, Real Decreto 2010/2005).

\section{Experimental design and diets}

A randomised complete block design was used with a $2 \times 2$ factorial arrangement including two treatment diets and two genders. Diets were based on maize, soybean meal, wheat, rapeseed meal, rice bran, soy oil and wheat bran, and were formulated by phase. This included a PC formulated to supply adequate levels of all nutrients in accordance with breeder recommendations issued in 2014 (these were identical to the 2019 recommendations (Aviagen Inc. NL, 2019a) except for avP in starter phase), but with reduced ME due to the expected contribution of $71 \mathrm{kcal} / \mathrm{kg} \mathrm{ME}$ from the xylanase included. The xylanase was a commercial product from Trichoderma reesei (Danisco Animal Nutrition and Health, IFF, Oegstgeest, the Netherlands) and dosed at 2,000 $\mathrm{XU} / \mathrm{kg}$ in all phases. The PP content of the diet was reduced by phase to $3.4 \mathrm{~g} / \mathrm{kg}$ (d 0 to 11 , starter), $3.3 \mathrm{~g} / \mathrm{kg}$ (d 11 to 22 , grower), $2.9 \mathrm{~g} / \mathrm{kg}$ (d 22 to 35 , finisher 1 ) and $2.8 \mathrm{~g} / \mathrm{kg}$ (d 35 to 42, finisher 2). Oat hulls were included to stimulate gizzard development (Sacranie et al., 2017) and soy hulls were used as a replacement material. The experimental diet (inorganic phosphate-free; IPF) was based on the PC but formulated with the complete absence of added $\mathrm{Pi}$, containing $1.5,1.5,1.4$ and $1.4 \mathrm{~g} / \mathrm{kg}$ digestible $\mathrm{P}$ in starter, grower, finisher 1 and finisher 2 diets, respectively, excluding the expected P-contribution of the phytase. The IPF diets were formulated with a $2 \mathrm{~g} / \mathrm{kg}$ reduction in calcium $(\mathrm{Ca}) \mathrm{vs}$ PC. The IPF diet was supplemented with a novel consensus bacterial 6-phytase variant expressed in T. reesei (PhyG; Danisco Animal Nutrition and Health, IFF) at a dose-level of 3,000 FTU/kg from d 0 to $11,2,000 \mathrm{FTU} / \mathrm{kg}$ from $\mathrm{d} 11$ to 22 and $1000 \mathrm{FTU} / \mathrm{kg}$ from d 22 to 42 . A negative control 
was not included, as the very low levels of P would have led to health and welfare issues (such as leg deformities) in the birds. The ingredient and calculated nutrient composition of the treatment diets is presented in Table 1.

Table 1. Ingredient and calculated nutrient content (g/kg, as fed basis) of the treatment diets, by phase. ${ }^{1}$

\begin{tabular}{|c|c|c|c|c|c|c|c|c|}
\hline & \multicolumn{2}{|c|}{ Starter (d 0 to 11$)$} & \multicolumn{2}{|c|}{ Grower (d 11 to 22 ) } & \multicolumn{2}{|c|}{ Finisher 1 (d 22 to 35 ) } & \multicolumn{2}{|c|}{ Finisher 2 (d 35 to 42 ) } \\
\hline & $\mathrm{PC}$ & IPF & $P C$ & IPF & $\mathrm{PC}$ & IPF & $\mathrm{PC}$ & IPF \\
\hline \multicolumn{9}{|l|}{ Ingredients $\mathrm{g} / \mathrm{kg}$} \\
\hline Maize & 240.1 & 244 & 284.1 & 283.8 & 341.6 & 340.4 & 371.1 & 369.8 \\
\hline Soybean meal & 299.9 & 299.5 & 298.8 & 298.1 & 280.4 & 279.5 & 260.3 & 259.9 \\
\hline Wheat & 200 & 200 & 200 & 200 & 200 & 200 & 200 & 200 \\
\hline Rapeseed meal & 70 & 70 & 56.3 & 57.4 & 27.2 & 28.4 & 26.6 & 27.2 \\
\hline Rice bran & 60 & 60 & 60 & 60 & 50 & 50 & 45 & 45 \\
\hline Soy oil & 51.9 & 50.5 & 40.1 & 40.3 & 44 & 44.4 & 42.6 & 43 \\
\hline Wheat bran & 20 & 20 & 10 & 10 & 10 & 10 & 10 & 10 \\
\hline Soy hulls & 5.0 & 16.9 & 3.4 & 15.2 & 3.2 & 14.8 & 3.2 & 14.5 \\
\hline Monocalcium phosphate & 15.4 & - & 11.6 & - & 10.2 & - & 9.4 & - \\
\hline Limestone & 12.8 & 14.2 & 12.7 & 12.4 & 11.4 & 10.5 & 11 & 9.7 \\
\hline Oat hulls & 10 & 10 & 10 & 10 & 10 & 10 & 10 & 10 \\
\hline Vitamin-mineral premix ${ }^{2}$ & 4 & 4 & 4 & 4 & 4 & 4 & 4 & 4 \\
\hline Salt & 3.9 & 3.9 & 3.9 & 3.9 & 3.7 & 3.7 & 3.7 & 3.7 \\
\hline DL-methionine & 3.1 & 3.1 & 2.5 & 2.5 & 2.2 & 2.2 & 1.7 & 1.7 \\
\hline L-lysine HCL & 3.0 & 3.0 & 1.8 & 1.8 & 1.6 & 1.6 & 1.3 & 1.3 \\
\hline L-threonine & 0.8 & 0.8 & 0.6 & 0.6 & 0.5 & 0.5 & 0.2 & 0.2 \\
\hline Phytase, FTU/kg & - & 3,000 & - & 2,000 & - & 1000 & - & 1000 \\
\hline Xylanase, XU/kg & 2,000 & 2,000 & 2,000 & 2,000 & 2,000 & 2,000 & 2,000 & 2,000 \\
\hline \multicolumn{9}{|l|}{ Calculated nutrients $(\mathrm{g} / \mathrm{kg})$} \\
\hline $\mathrm{ME}, \mathrm{kcal} / \mathrm{kg}$ & 2,850 & 2,850 & 2,928 & 2,928 & 3,029 & 3,029 & 3,049 & 3,049 \\
\hline Dry matter & 895.1 & 893.5 & 892.4 & 891.2 & 890.9 & 889.8 & 889.7 & 888.7 \\
\hline Crude protein & 223.6 & 224.8 & 217.8 & 219 & 200.9 & 202 & 192.2 & 193.3 \\
\hline Crude fat & 71.1 & 70.1 & 60.2 & 60.5 & 64.9 & 65.5 & 64.1 & 64.7 \\
\hline Calcium & 9.2 & 7.2 & 8.4 & 6.4 & 7.4 & 5.4 & 7.0 & 5.0 \\
\hline Digestible $\mathrm{P}^{3,4}$ & 4.5 & 1.5 & 3.7 & 1.5 & 3.4 & 1.4 & 3.2 & 1.4 \\
\hline Non-phytate P & 4.9 & 1.4 & 3.7 & 1.1 & 3.4 & 1.1 & 3.2 & 1.1 \\
\hline Total P & 8.3 & 4.8 & 7.0 & 4.4 & 6.3 & 4.0 & 6.0 & 3.9 \\
\hline $\mathrm{Ca}: \mathrm{P}^{5}$ & 1.1 & 1.5 & 1.2 & 1.5 & 1.2 & 1.4 & 1.2 & 1.3 \\
\hline Phytate-P & 3.4 & 3.4 & 3.3 & 3.3 & 2.9 & 2.9 & 2.8 & 2.8 \\
\hline Sodium & 1.9 & 1.9 & 1.9 & 1.9 & 1.8 & 1.8 & 1.8 & 1.8 \\
\hline Chloride & 2.7 & 2.7 & 2.7 & 2.7 & 2.6 & 2.6 & 2.6 & 2.6 \\
\hline Dig. Lys & 12.2 & 12.2 & 11.0 & 11.0 & 10.0 & 10.0 & 9.2 & 9.2 \\
\hline Dig. Met + Cys & 9.1 & 9.1 & 8.4 & 8.4 & 7.6 & 7.6 & 7.0 & 7.0 \\
\hline Dig. Met & 6.0 & 6.0 & 5.4 & 5.4 & 4.8 & 4.8 & 4.3 & 4.3 \\
\hline Dig. Thr & 7.6 & 7.6 & 7.3 & 7.3 & 6.6 & 6.6 & 6.1 & 6.1 \\
\hline Dig. Trp & 2.2 & 2.2 & 2.2 & 2.2 & 2.0 & 2.0 & 1.9 & 1.9 \\
\hline Dig. Arg & 13.0 & 13.0 & 12.8 & 12.8 & 11.7 & 11.7 & 11.2 & 11.2 \\
\hline Dig. Ile & 7.8 & 7.8 & 7.7 & 7.7 & 7.1 & 7.1 & 6.8 & 6.8 \\
\hline Dig. Val & 8.6 & 8.6 & 8.4 & 8.4 & 7.8 & 7.8 & 7.4 & 7.4 \\
\hline
\end{tabular}

${ }^{1} \mathrm{IPF}=$ inorganic phosphate free; $\mathrm{PC}=$ positive control.

${ }^{2}$ Supplied per kilogram of diet: retinyl acetate: $344 \mathrm{mg}$; cholecalciferol: $0.12 \mathrm{mg}$; all-rac-alpha-tocophery-acetate- $50 \%: 45 \mathrm{mg}$; menadione sodium bisulfite-50\%: $3 \mathrm{mg}$; thiamine mononitrate- $98 \%: 3 \mathrm{mg}$; riboflavin-80\%: $9 \mathrm{mg}$; pyridoxine monochloride- $99 \%: 4.5 \mathrm{mg}$ : cyanocobalamine- $1 \mathrm{~g} / \mathrm{kg}: 40 \mathrm{mg}$; folic acid-88\%: $1.8 \mathrm{mg}$; biotin-2\%: $150 \mathrm{mg}$; calcium panthotenate-98\%: $16.5 \mathrm{mg}$; nicotinic acid-98\%: $51 \mathrm{mg}$; $\mathrm{Mn}$ (as $\mathrm{MnSO}_{4} \cdot \mathrm{H}_{2} \mathrm{O}$ ): $90 \mathrm{mg}$; Zn (as ZnO): $66 \mathrm{mg} ; \mathrm{I}$ (as KI): $1.2 \mathrm{mg} ; \mathrm{Fe}_{(\mathrm{as} \mathrm{FeSO}} \cdot \mathrm{H}_{2} \mathrm{O}$ ): $54 \mathrm{mg} ; \mathrm{Cu}$ (as $\mathrm{CuSO}_{4} \cdot 5 \mathrm{H}_{2} 0$ ): $12 \mathrm{mg}$; Se (as $\mathrm{NaSeO}_{3}$ ): $0.18 \mathrm{mg}$; butylhydroxytoluene: $25 \mathrm{mg}$; calcium formate, $5 \mathrm{mg}$; silicic acid, dry and precipitated, $25 \mathrm{mg}$; calcium stearate, $25 \mathrm{mg}$; calcium carbonate to $4 \mathrm{~g}$.

${ }^{3}$ Excluding the contribution from added phytase in the IPF diets.

${ }^{4}$ Calculated based on the P digestibility coefficient values of different feed ingredients published in the CVB Feed Table 2018 (CVB, 2018).

${ }^{5}$ Calculated as total $\mathrm{Ca}$ to total $\mathrm{P}$ rather than $\mathrm{Ca}$ :digP because the value for digestible $\mathrm{P}$ excludes the contribution of the phytase. 
Feeds were prepared in bulk by mixing all ingredients except amino acids, vitamin and mineral premix and enzymes. The amino acids, vitamin and mineral and enzymes were premixed in $10 \mathrm{~kg}$ of basal feed ingredients prior to addition to the feed mixer to ensure homogenous distribution. Diets were provided as phased diets in crumble form during starter phase ( $\mathrm{d} 0$ to 11 ) and pellet form during grower (d 11 to 22) and finisher 1 and 2 (d 22 to 35 and d 35 to 42 ) phases. Pelleting was conducted at $80^{\circ} \mathrm{C}$ with a conditioning time of between 13 and 18 seconds (dependent on the production rate, which was between 1,500 and $600 \mathrm{~kg} / \mathrm{h}$ ). Diets and water were provided ad libitum for the duration of the study.

\section{Birds and housing}

A total of 1,248 Ross 308 broiler hatchlings were obtained from a commercial hatchery where they had been feathersexed, and were randomly assigned to 24 floor pens (52 birds/pen, 12 pens/treatment diet, six containing males and six containing females, with a stocking density at 42 days of age of $33 \mathrm{~kg} / \mathrm{m}^{2}$ ). Pens were bedded with fresh wood shavings that had been disinfected with glutaraldehyde and were situated in an environmentally controlled broiler house with a lighting regime of LD24:0 h during d 0 to 2, LD18:6 h during d 3 to 7, and LD14:10 $\mathrm{h}$ thereafter. Temperature was initially maintained at 32 to $34{ }^{\circ} \mathrm{C}$ and then gradually reduced to 19 to $21^{\circ} \mathrm{C}$ from d 3 to 28 and maintained at that temperature thereafter. During the first week of the study, individual birds were selected at random in the required numbers for later sampling and labelled by feather spraying. This was done to prevent later bias that may have been introduced if selection is done visually (due to the potential tendency to select larger or smaller birds).

\section{Sampling and measurements}

Birds and feed were weighed on a per pen basis on $\mathrm{d} 0$, $11,22,35$ and 42 and were used to calculate body weight (BW), average daily feed intake (ADFI) and average daily gain (ADG). On d 11, 22 and 42, all birds were weighed individually to assess uniformity. Pens were monitored daily for bird mortality which was recorded and used to calculate mortality-corrected feed conversion ratio (FCR). In addition, for the overall period (d 0 to 42 ), BW-corrected FCR (FCRc) was calculated by correcting values by 3 points per $100 \mathrm{~g}$ of BW difference from the respective $\mathrm{PC}$.

On d 11, 22 and 42, two selected (colour sprayed) birds from each pen were euthanised by cervical dislocation, and their right tibia bones collected for the determination of ash content. Tibias were frozen at $-20{ }^{\circ} \mathrm{C}$ before analysis.

\section{Chemical analysis}

Diet samples were analysed for dry matter (DM), crude protein, ash, $\mathrm{P}$ and $\mathrm{Ca}$. Phytase activity was measured by IRTA and xylanase was analysed by Danisco Animal Nutrition Research Centre (Brabrand, Denmark).

Tibias were thawed prior to the manual removal of fibula, muscle and connective tissue. The cleaned bones were then oven dried and ashed according to the method previously described by Dersjant-Li et al. (2020b). Dry matter, CP and ash were analysed according to AOAC methods 925.09, 942.05 and 968.06, respectively (AOAC, 2000). Phosphorus in feed was analysed according to AOAC method 965.17 (AOAC, 1990). Calcium in feed was analysed by inductively coupled plasma mass spectrometry (ICP-MS; Agilent Technologies model 7700X, Agilent Technologies Inc., Santa Clara, CA, USA) at Office Laboratory Castellbisbal (Barcelona, Spain) according to the method described by Pacquette and Thompson (2018). Phytate phosphorus, as inositol hexa-phosphate $\left(\mathrm{IP}_{6}\right)$ was determined at Danisco Animal Nutrition Research Centre using a modified version of the HPLC method described by Skoglund et al. (1997). Phytase activity was determined according to a modified version of the 2000.12 AOAC method (Engelen et al., 2001). One phytase unit (FTU) was defined as the amount of enzyme that liberated $1 \mu \mathrm{mol}$ of inorganic phosphate per minute from a sodium phytate substrate at a $\mathrm{pH}$ of 5.5 and a temperature of $37{ }^{\circ} \mathrm{C}$. Xylanase activity was determined according to the method of Romero et al. (2014), where one $\mathrm{XU}$ was defined as the amount of enzyme that released 0.48 $\mu$ mol of reducing sugar as xylose from wheat arabinoxylan per minute at $\mathrm{pH} 4.2$ and $50{ }^{\circ} \mathrm{C}$. All feed analysis was conducted in duplicate.

\section{Statistical analysis}

Pen was defined as the experimental unit. Data were analysed by two-way ANOVA to evaluate main effects of treatment and gender, and their interaction, on performance and bone ash measures. Where a significant interaction was identified, Tukey's test was used to separate the means. Analyses were conducted using the Fit Model platform of JMP v14.0 (SAS Institute Inc., Cary, NC, USA) with treatment and gender included as fixed effects and block as a random effect. Differences were considered significant at $P<0.05$. Where $0.05<P<0.1$, this was considered a tendency.

\section{Results}

Analysed levels of nutrients and enzyme activities in the diets are presented in Table 2. Analysed Ca was higher than formulated (on average, by $29.5 \%$ ). Analysed total P was consistently within $10 \%$ of formulated values. Phytase activities were close to target levels in all treatments and phases. Xylanase activities were more variable, varying 
by a maximum of $14 \%$ below target (finisher 2 phase IPF) to a maximum of $34 \%$ above target (finisher 2 phase PC).

\section{Growth performance and mortality}

No interactions between treatment and gender were observed for growth performance parameters in each phase. During all growth phases, the ADG and ADFI of birds fed the IPF diet were equivalent to or greater than, and the FCR was equivalent to or less than, the respective value achieved by the PC (Table 3 ). From d 0 to $11, \mathrm{ADG}$, ADFI and FCR in the IPF-fed birds were equivalent to the corresponding values in those fed PC. From d 11 to 22, ADG and ADFI in birds fed IPF were higher than in the PC groups $(P<0.001$ in all cases). From d 22 to 35 , ADG in birds fed IPF was greater than $(P<0.01)$, whereas ADFI and FCR did not differ from the PC groups, and from d 35 to 42, ADG tended to be higher in birds fed IPF $(P=0.063)$ and FCR tended to be lower $(P<0.10)$ compared to $P C$ groups (Table 3). The positive effect of treatment IPF vs PC on growth performance was greatest from d 11 to 22 (ADG $+6.02 \%$, ADFI $+4.57 \%$, vs PC, $P<0.001$, Table 3 ).

On a cumulative basis, compared to birds fed PC, those given IPF had higher BW, ADG, and ADFI during the periods d 0 to 22 and d 0 to $35(P<0.05$ in all cases). From $\mathrm{d} 0$ to 35 birds fed IPF had lower FCR and FCRc (-1.5 and 3.7 points respectively vs $\mathrm{PC}, P<0.05$ ) (Table 4 ). For the overall period ( $\mathrm{d} 0$ to 42 ), compared to PC, birds in treatment IPF exhibited higher BW at 42 days of age $(+3.97 \%, P<0.01)$, ADG $(+4.10 \%, P<0.01)$, lower FCR ( -3 points) and FCRc (-6.3 points), whereas ADFI tended to be greater $(+1.94 \%$, $P=0.054$; Table 4). Mortality levels were at or below $3 \%$ across treatments and growth phases and did not differ by gender or treatment during any phase (Table 4). During d 0 to 35 and d 0 to 42, the European performance efficiency factor (EPFF) was greater in IPF than PC birds and in males than females $(P<0.05$, Table 4$)$.
Independent of treatment, beyond the starter phase (d 11 onwards) male birds consistently exhibited higher BW, ADG and ADFI than females, both during individual growth phases (d 11 to 22,22 to 35 and 35 to 42 ) and cumulatively (Table $4 ; P<0.05$ ). The FCR of males was lower than that of females during finisher 1 phase only (d 22 to $35,-2.2$ points, $P=0.05$ ).

No interactions between treatment and gender were observed for ADG or ADFI. For FCR, there was an interaction between these factors from d 0 to $22(P<0.01)$ and d 0 to $42(P<0.05)$ (Table 4$)$. There was a tendency towards an interaction between diet and gender from $\mathrm{d} 11$ to $22(P=0.051)$ (Table 3 ) and during the overall period for FCRc (d 0 to $42, P=0.052$; Table 4 ). In all of these cases, the effect of the IPF treatment in reducing FCR vs PC was greater in males than females (Table 4). For the overall period ( $\mathrm{d} 0$ to 42 ), feeding IPF reduced FCR vs PC by 5.1 points in males $(P<0.05)$ and by 1.1 points in females $(P>0.05)$.

The uniformity of bird BW by treatment and by gender was assessed (data not shown). Body weight CVs were, on average, 11.8 .11 .9 and $10.2 \%$ at $\mathrm{d} 11,22$ and 42 , respectively. There were no main effects or interaction between diet and gender on $\mathrm{BW} C \mathrm{CV}$, except for $\mathrm{d} 22$, where there was a tendency $(P<0.10)$ for lower $\mathrm{CV}$ in $\mathrm{BW}$ in the IPF group (11.3\%) vs PC (12.6\%), and at $\mathrm{d} 42 \mathrm{~d}$ the $\mathrm{CV}$ of BW was higher in males $(11.1 \%)$ than females $(9.4 \% ; P<0.05)$.

\section{Tibia ash}

Tibia ash, dry weight relative to live weight and ash weight relative to live weight were not different at any sampling time points (Table 5). There was no effect of gender on these response measures, except at $d 42$ when tibia dry weight and ash weight relative to live weight were reduced in females vs males $(P<0.05$; Table 5$)$. No interactions between treatment and gender were observed.

Table 2. Analysed nutrient content ( $\mathrm{g} / \mathrm{kg}$ as fed basis) and enzyme activities of the treatment diets, by phase. ${ }^{1}$

\begin{tabular}{|c|c|c|c|c|c|c|c|c|}
\hline \multirow[t]{2}{*}{ Parameter } & \multicolumn{2}{|c|}{ Starter (d 0 to 11$)$} & \multicolumn{2}{|c|}{ Grower (d 11 to 22 ) } & \multicolumn{2}{|c|}{ Finisher 1 (d 22 to 35$)$} & \multicolumn{2}{|c|}{ Finisher 2 (d 35 to 42 ) } \\
\hline & $P C$ & IPF & $\mathrm{PC}$ & IPF & $P C$ & IPF & $\mathrm{PC}$ & IPF \\
\hline Crude protein & 227 & 228.6 & 216.6 & 216.9 & 199.8 & 200.2 & 195.4 & 197.1 \\
\hline Ash & 63.2 & 54.7 & 58.3 & 50.5 & 53.3 & 51.8 & 51 & 44 \\
\hline Calcium & 11.5 & 9.2 & 10.2 & 7.9 & 9.4 & 7.4 & 8.9 & 7.1 \\
\hline Phosphorus & 8.3 & 5.2 & 6.7 & 4.1 & 5.8 & 3.6 & 5.6 & 3.6 \\
\hline Phytate- $P^{2}$ & 3.32 & 3.42 & 3.19 & 3.29 & 2.87 & 2.97 & 2.8 & 2.9 \\
\hline $\mathrm{Ca}: \mathrm{P}$ & 1.39 & 1.77 & 1.52 & 1.93 & 1.62 & 2.06 & 1.59 & 1.97 \\
\hline Phytase, FTU/kg & 82 & 3,084 & 67 & 2,255 & 94 & 1,028 & 47 & 917 \\
\hline Xylanase, XU/kg & 2,125 & 2,207 & 1,742 & 2,524 & 2,657 & 1,984 & 2,684 & 1,728 \\
\hline
\end{tabular}

${ }^{1} \mathrm{IPF}=$ inorganic phosphate free; $\mathrm{PC}=$ positive control.

${ }^{2}$ Analysed phytate- $P$ in feed was based on the analysed phytate- $P$ level in the ingredients and their inclusion rate in the diet (all ingredients containing phytate $P$ were analysed). 
Table 3. Effect of treatment and gender on broiler growth performance measures, by phase.1,2,3

\begin{tabular}{|c|c|c|c|c|c|}
\hline Starter (d 0 to 11 ) & Gender & No. of observations & ADG (g/bird) & ADFI (g/bird) & $\mathrm{FCR}(\mathrm{g} / \mathrm{g})$ \\
\hline $\begin{array}{l}\text { Treatment means } \\
\text { PC } \\
\text { PC } \\
\text { IPF }^{2} \\
\text { IPF } \\
\text { SEM }\end{array}$ & $\begin{array}{l}\text { Female } \\
\text { Male } \\
\text { Female } \\
\text { Male }\end{array}$ & $\begin{array}{l}6 \\
6 \\
6 \\
6\end{array}$ & $\begin{array}{l}20.7 \\
21.2 \\
20.7 \\
21.3 \\
0.310\end{array}$ & $\begin{array}{l}23.1 \\
23.5 \\
22.9 \\
23.4 \\
0.253\end{array}$ & $\begin{array}{l}1.112 \\
1.111 \\
1.106 \\
1.100 \\
0.007\end{array}$ \\
\hline $\begin{array}{l}\text { Main effect means } \\
\text { Treatment } \\
\text { Gender } \\
\text { SEM } \\
P \text {-value, treatment } \\
P \text {-value, gender } \\
P \text {-value, treatment } \times \text { gender interaction }\end{array}$ & $\begin{array}{l}\text { PC } \\
\text { IPF } \\
\text { Female } \\
\text { Male }\end{array}$ & $\begin{array}{l}12 \\
12 \\
12 \\
12\end{array}$ & $\begin{array}{l}21.0 \\
21.0 \\
20.7 \\
21.2 \\
0.259 \\
0.905 \\
0.065 \\
0.869\end{array}$ & $\begin{array}{l}23.3 \\
23.2 \\
23.0^{b} \\
23.5^{a} \\
0.208 \\
0.476 \\
0.039 \\
0.995\end{array}$ & $\begin{array}{l}1.112 \\
1.103 \\
1.109 \\
1.106 \\
0.006 \\
0.146 \\
0.504 \\
0.694\end{array}$ \\
\hline Grower (d 11 to 22 ) & & & & & \\
\hline $\begin{array}{l}\text { Treatment means } \\
\text { PC } \\
\text { PC } \\
\text { IPF } \\
\text { IPF } \\
\text { SEM } \\
\text { Main effect means } \\
\text { Treatment } \\
\text { Gender } \\
\text { SEM } \\
P \text {-value, treatment } \\
P \text {-value, gender } \\
P \text {-value, treatment } \times \text { gender interaction }\end{array}$ & $\begin{array}{l}\text { PC } \\
\text { IPF } \\
\text { Female } \\
\text { Male }\end{array}$ & $\begin{array}{l}12 \\
12 \\
12 \\
12\end{array}$ & $\begin{array}{l}54.9 \\
61.2 \\
58.3 \\
64.9 \\
0.625 \\
\\
58.1^{\mathrm{b}} \\
61.6^{\mathrm{a}} \\
56.6^{\mathrm{b}} \\
63.1^{\mathrm{a}} \\
0.509 \\
<0.001 \\
<0.001 \\
0.820\end{array}$ & $\begin{array}{l}74.7 \\
82.7 \\
78.9 \\
85.7 \\
0.755 \\
\\
78.7^{\mathrm{b}} \\
82.3^{\mathrm{a}} \\
76.8^{\mathrm{b}} \\
84.2^{\mathrm{a}} \\
0.911 \\
<0.001 \\
<0.001 \\
0.446\end{array}$ & $\begin{array}{l}1.361 \\
1.350 \\
1.352 \\
1.320 \\
0.003 \\
\\
1.356^{a} \\
1.336^{b} \\
1.357^{a} \\
1.335^{b} \\
0.005 \\
0.001 \\
0.001 \\
0.051\end{array}$ \\
\hline Finisher 1 (d 22 to 35$)$ & & & & & \\
\hline $\begin{array}{l}\text { Treatment means } \\
\text { PC } \\
\text { PC } \\
\text { IPF } \\
\text { IPF } \\
\text { SEM } \\
\text { Main effect means } \\
\text { Treatment } \\
\text { Gender } \\
\text { SEM } \\
P \text {-value, treatment } \\
P \text {-value, gender } \\
P \text {-value, treatment } \times \text { gender interaction }\end{array}$ & $\begin{array}{l}\text { PC } \\
\text { IPF } \\
\text { Female } \\
\text { Male }\end{array}$ & $\begin{array}{l}12 \\
12 \\
12 \\
12\end{array}$ & $\begin{array}{l}86.7 \\
102.7 \\
89.0 \\
105.6 \\
0.895 \\
\\
94.7^{\mathrm{b}} \\
97.3^{\mathrm{a}} \\
87.9^{\mathrm{b}} \\
104.2^{\mathrm{a}} \\
0.623 \\
0.011 \\
<0.001 \\
0.758\end{array}$ & $\begin{array}{l}136.0 \\
160.0 \\
139.4 \\
161.9 \\
1.625 \\
\\
148.0 \\
150.6 \\
137.7^{\mathrm{b}} \\
160.9^{\mathrm{a}} \\
1.131 \\
0.129 \\
<0.001 \\
0.648\end{array}$ & $\begin{array}{l}1.569 \\
1.558 \\
1.566 \\
1.532 \\
0.008 \\
\\
1.563 \\
1.549 \\
1.567 \\
1.545 \\
0.011 \\
0.199 \\
0.052 \\
0.301\end{array}$ \\
\hline Finisher 2 (d 35 to 42 ) & & & & & \\
\hline $\begin{array}{l}\text { Treatment means } \\
\text { PC } \\
\text { PC } \\
\text { IPF } \\
\text { IPF } \\
\text { SEM }\end{array}$ & $\begin{array}{l}\text { Female } \\
\text { Male } \\
\text { Female } \\
\text { Male }\end{array}$ & $\begin{array}{l}6 \\
6 \\
6 \\
6\end{array}$ & $\begin{array}{l}74.9 \\
86.1 \\
78.3 \\
92.8 \\
2.349\end{array}$ & $\begin{array}{l}169.1 \\
205.0 \\
174.1 \\
203.2 \\
2.085\end{array}$ & $\begin{array}{l}2.258 \\
2.396 \\
2.230 \\
2.196 \\
0.060\end{array}$ \\
\hline Main effect means & & & & & \\
\hline $\begin{array}{l}\text { Treatment } \\
\text { Gender } \\
\text { SEM } \\
P \text {-value, treatment } \\
P \text {-value, gender } \\
P \text {-value, treatment } \times \text { gender interaction }\end{array}$ & $\begin{array}{l}\text { PC } \\
\text { IPF } \\
\text { Female } \\
\text { Male }\end{array}$ & $\begin{array}{l}12 \\
12 \\
12 \\
12\end{array}$ & $\begin{array}{l}80.5 \\
85.5 \\
76.6^{\mathrm{b}} \\
89.4^{\mathrm{a}} \\
1.542 \\
0.063 \\
<0.001 \\
0.519\end{array}$ & $\begin{array}{l}187.0 \\
188.6 \\
171.6^{b} \\
204.1^{a} \\
1.490 \\
0.454 \\
<0.001 \\
0.124\end{array}$ & $\begin{array}{l}2.327 \\
2.213 \\
2.244 \\
2.296 \\
0.039 \\
0.095 \\
0.425 \\
0.197\end{array}$ \\
\hline
\end{tabular}

${ }^{1} \mathrm{ADG}=$ average daily gain; $\mathrm{ADFI}=$ average daily feed intake; $\mathrm{FCR}=$ feed conversion ratio; $\mathrm{IPF}=$ inorganic phosphate free; $\mathrm{PC}=$ positive control.

2 The statistical analysis was a $2 \times 2$ factorial Analysis of Variance (2-way ANOVA) with 2 treatments and 2 genders. All growth performance parameters (ADG, ADFI and FCR) are corrected for mortality.

${ }^{3}$ Main effect means with no common superscripts are significantly different at a $P<0.05$. 
Inorganic phosphate replacement broilers

Table 4. Effect of treatment and gender on broiler growth performance measures, cumulative of $0-22,0-35$ and $0-42$ days of age. ${ }^{1,2,3}$

\begin{tabular}{|c|c|c|c|c|c|c|c|c|c|}
\hline d 0 to 22 & Gender & Treatment & $\begin{array}{l}\text { BW (g/bird) } \\
\text { d } 22\end{array}$ & ADG (g/bird) & ADFI (g/bird) & FCR $(g / g)$ & Mortality (\%) & $\operatorname{FCRc}(g / g)^{4}$ & EPEF $^{5}$ \\
\hline \multicolumn{10}{|l|}{ Treatment means ${ }^{6}$} \\
\hline PC & Female & & 872 & 37.8 & 48.8 & $1.291^{a}$ & 1.28 & - & - \\
\hline PC & Male & & 947 & 41.2 & 53.0 & $1.287^{\mathrm{a}}$ & 0.32 & - & - \\
\hline IPF & Female & & 910 & 39.5 & 50.8 & $1.285^{\mathrm{a}}$ & 2.24 & - & - \\
\hline IPF & Male & & 984 & 42.9 & 54.2 & $1.262^{b}$ & 1.92 & - & - \\
\hline SEM & & & 9.18 & 0.415 & 0.539 & 0.003 & 0.842 & - & - \\
\hline \multicolumn{10}{|l|}{ Main effect means ${ }^{7}$} \\
\hline \multirow[t]{2}{*}{ Treatment } & & PC & $910^{\mathrm{b}}$ & $39.5^{\mathrm{b}}$ & $50.9^{b}$ & 1.289 & 0.80 & - & - \\
\hline & & IPF & $947^{a}$ & $41.2^{\mathrm{a}}$ & $52.5^{\mathrm{a}}$ & 1.274 & 2.08 & - & - \\
\hline \multirow[t]{2}{*}{ Gender } & Female & & $891^{b}$ & $38.7^{b}$ & $49.8^{b}$ & 1.288 & 1.76 & - & - \\
\hline & Male & & $965^{a}$ & $42.1^{\mathrm{a}}$ & $53.6^{\mathrm{a}}$ & 1.274 & 1.12 & - & - \\
\hline SEM & & & 7.83 & 0.355 & 0.459 & 0.002 & 0.617 & - & - \\
\hline$P$-value, treatment & & & $<0.001$ & $<0.001$ & 0.001 & $<0.001$ & 0.135 & - & - \\
\hline$P$-value, gender & & & $<0.001$ & $<0.001$ & $<0.001$ & $<0.001$ & 0.442 & - & - \\
\hline$P$-value, treatment $\times$ gender interaction & & & 0.988 & 0.994 & 0.310 & 0.004 & 0.698 & - & - \\
\hline d 0 to 35 & & & d 35 & & & & & & \\
\hline \multicolumn{10}{|l|}{ Treatment means 6} \\
\hline PC & Female & & 1,999 & 56.0 & 81.0 & 1.447 & 1.28 & 1.447 & 382 \\
\hline PC & Male & & 2,282 & 64.0 & 92.5 & 1.444 & 1.28 & 1.444 & 438 \\
\hline IPF & Female & & 2,068 & 57.9 & 83.5 & 1.441 & 2.88 & 1.421 & 390 \\
\hline IPF & Male & & 2,358 & 66.2 & 93.9 & 1.419 & 1.92 & 1.396 & 458 \\
\hline SEM & & & 19.03 & 0.543 & 0.889 & 0.006 & 0.964 & 0.007 & 5.075 \\
\hline \multicolumn{10}{|l|}{ Main effect means ${ }^{7}$} \\
\hline \multirow[t]{2}{*}{ Treatment } & & PC & $2,141^{b}$ & $60.0^{\mathrm{b}}$ & $86.7^{\mathrm{b}}$ & $1.445^{\mathrm{a}}$ & 1.28 & $1.445^{\mathrm{a}}$ & 410 \\
\hline & & IPF & $2,213^{a}$ & $62.1^{a}$ & $88.7^{a}$ & $1.430^{b}$ & 2.40 & $1.408^{b}$ & 424 \\
\hline \multirow[t]{2}{*}{ Gender } & Female & & $2,033^{b}$ & $56.9^{b}$ & $82.2^{b}$ & $1.444^{\mathrm{a}}$ & 2.08 & 1.434 & $386^{b}$ \\
\hline & Male & & $2,320^{\mathrm{a}}$ & $65.1^{\mathrm{a}}$ & $93.2^{\mathrm{a}}$ & $1.431^{b}$ & 1.60 & 1.420 & $448^{\mathrm{a}}$ \\
\hline SEM & & & 14.53 & 0.414 & 0.665 & 0.004 & 0.728 & 0.005 & 3.588 \\
\hline$P$-value, treatment & & & 0.001 & 0.001 & 0.031 & 0.019 & 0.229 & $<0.001$ & 0.012 \\
\hline$P$-value, gender & & & $<0.001$ & $<0.001$ & $<0.001$ & 0.046 & 0.599 & 0.051 & $<0.001$ \\
\hline$P$-value, treatment $\times$ gender interaction & & & 0.830 & 0.832 & 0.530 & 0.104 & 0.599 & 0.108 & 0.254 \\
\hline \multicolumn{3}{|l|}{ d 0 to 42} & d 42 & & & & & & \\
\hline \multicolumn{10}{|l|}{ Treatment means ${ }^{6}$} \\
\hline PC & Female & & 2,524 & 59.1 & 95.5 & $1.615^{\mathrm{a}}$ & 1.92 & 1.615 & 359 \\
\hline PC & Male & & 2,884 & 67.7 & 110.5 & $1.632^{\mathrm{a}}$ & 2.88 & 1.632 & 403 \\
\hline IPF & Female & & 2,616 & 61.3 & 98.4 & $1.604^{\mathrm{ab}}$ & 2.88 & 1.577 & 371 \\
\hline IPF & Male & & 3,007 & 70.6 & 111.7 & $1.581^{\mathrm{b}}$ & 4.17 & 1.544 & 428 \\
\hline SEM & & & 29.18 & 0.694 & 0.986 & 0.008 & 1.214 & 0.012 & 5.982 \\
\hline \multicolumn{10}{|l|}{ Main effect means ${ }^{7}$} \\
\hline \multirow[t]{2}{*}{ Treatment } & & PC & $2,704^{b}$ & $63.4^{b}$ & 103.0 & 1.623 & 2.40 & $1.623^{\mathrm{a}}$ & $381^{b}$ \\
\hline & & IPF & $2,811^{a}$ & $66.0^{\mathrm{a}}$ & 105.0 & 1.593 & 3.53 & $1.561^{b}$ & $400^{a}$ \\
\hline \multirow[t]{2}{*}{ Gender } & Female & & $2,570^{b}$ & $60.2^{b}$ & $96.9^{b}$ & 1.609 & 2.40 & 1.596 & $365^{b}$ \\
\hline & Male & & $2,946^{a}$ & $69.2^{\mathrm{a}}$ & $111.1^{\mathrm{a}}$ & 1.607 & 3.53 & 1.588 & $416^{a}$ \\
\hline SEM & & & 20.55 & 0.489 & 0.713 & 0.006 & 0.947 & 0.009 & 4.156 \\
\hline$P$-value, treatment & & & 0.002 & 0.002 & 0.052 & 0.002 & 0.313 & $<0.001$ & 0.008 \\
\hline$P$-value, gender & & & $<0.001$ & $<0.001$ & $<0.001$ & 0.724 & 0.313 & 0.538 & $<0.001$ \\
\hline$P$-value, treatment $\times$ gender Interaction & & & 0.607 & 0.608 & 0.385 & 0.021 & 0.884 & 0.0521 & 0.287 \\
\hline
\end{tabular}

${ }^{1} \mathrm{ADG}=$ average daily gain; $\mathrm{ADFI}=$ average daily feed intake; $\mathrm{FCR}=$ feed conversion ratio; $\mathrm{IPF}=$ inorganic phosphate free; $\mathrm{PC}=$ positive control.

2 The statistical analysis was a $2 \times 2$ factorial Analysis of Variance (two-way ANOVA) with 2 treatments and 2 genders. All growth performance parameters (ADG, $\mathrm{ADFI}$ and FCR) are corrected for mortality.

${ }^{3}$ Treatment or main effect means in the same column with no common superscripts are significantly different at a probability level of $P<0.05$.

${ }^{4}$ FCRc: body weight corrected FCR, calculated by correction of FCR values by 3 points per $100 \mathrm{~g}$ of BW difference from the respective PC.

${ }^{5}$ EPEF, European performance efficiency factor (Aviagen Inc., 2018) $=$ ADG $(\mathrm{g}) \times(100$-mortality $(\%)) /(10 \times \mathrm{FCR})$.

${ }^{6}$ Number of observations $=6$.

${ }^{7}$ Number of observations $=12$. 
Table 5. Effect of treatment and gender on tibia ash content, tibia dry weight relative to live weight, and tibia ash weight relative to live weight of the sampled birds at 11,22 and 42 days of age. $1,2,3$

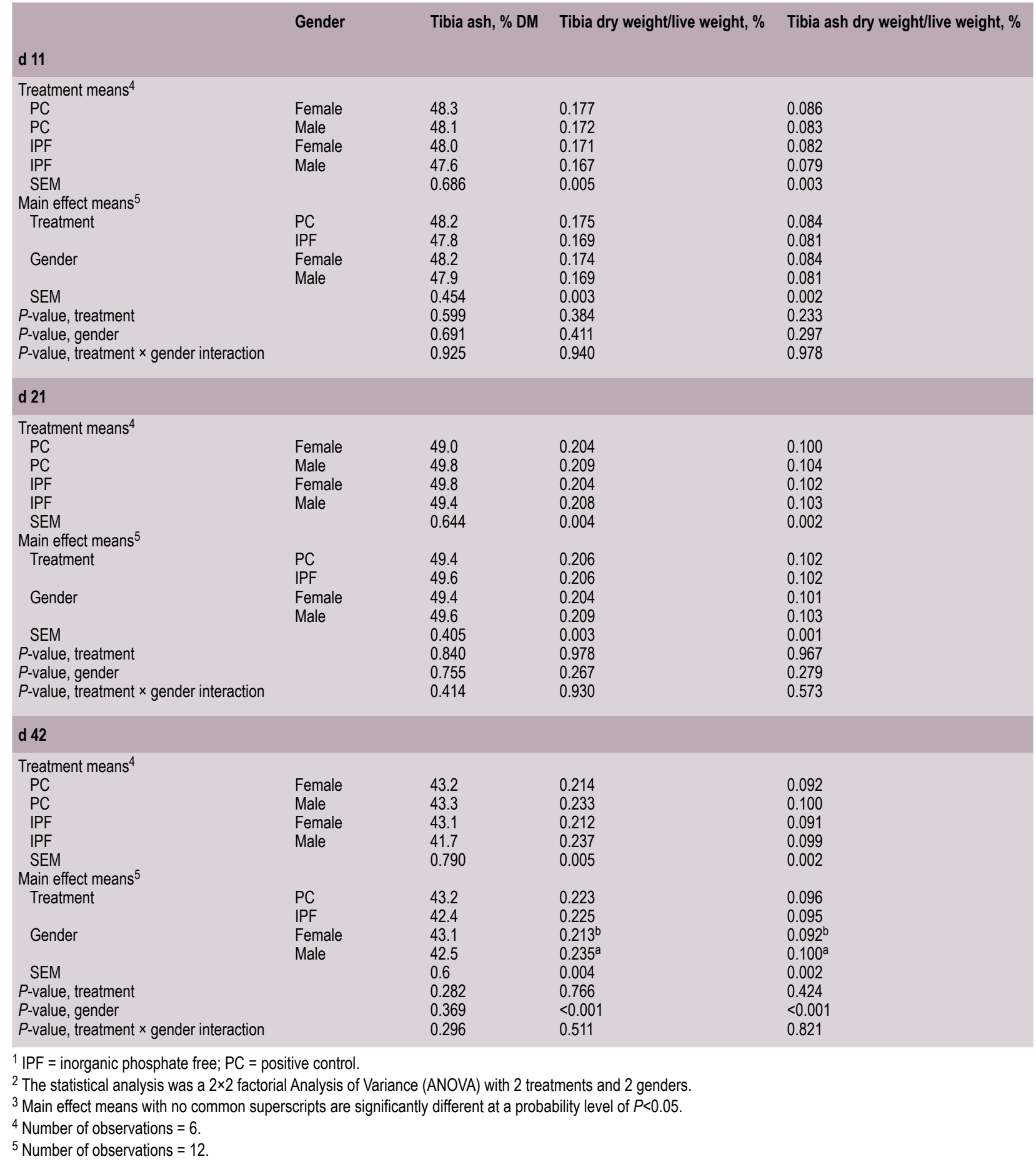

\section{Discussion}

Details of the origin, development and characteristics of the novel consensus phytase variant (PhyG) have been published elsewhere (Christensen et al., 2020; Ladics et al., 2020). The first proof of concept evaluation of PhyG in $\mathrm{Pi}$-free diets was recently reported by Marchal et al. (2021).
In that publication, a dose level of $1000 \mathrm{FTU} / \mathrm{kg}$ during all phases or a phased dosing strategy with high dose in starter phase $(3,000 \mathrm{FTU} / \mathrm{kg}$, or 2,000 FTU $/ \mathrm{kg}$ in combination with xylanase) decreasing to a lower dose in finisher phases (1000 FTU $/ \mathrm{kg}$ ), maintained growth performance, bone strength and mineralisation, equivalent to a $\mathrm{PC}$ diet from 0 to 42 days of age, in two trials. There was some evidence from both 
trials that the phased dosing strategy produced superior growth performance to $1000 \mathrm{FTU} / \mathrm{kg}$ in all phases, with higher ADG during $\mathrm{d} 0$ to 10 (trial 1) or $\mathrm{d} 11$ to 21 (trial 2) and lower overall FCRc ( -6 points) in trial 1. Given this, and the known higher $P$ requirement of birds in the starter phase, it was decided to implement the phased dosing strategy in the present study.

The control diets in the trials reported by Marchal et al. (2021) contained no exogenous enzymes and, by design, the diets in all phases contained high levels of phytate ( $\geq 3.3 \mathrm{~g} / \mathrm{kg}$ PP) to ensure sufficient substrate for the phytase. The present study employed a more systematically graded reduction in PP by phase, with the aim of optimising the enzyme-to-substrate ratio. Xylanase was added to the control as a background enzyme because its supplementation of high fibre broiler diets is common practice to improve the digestibility of NSPs and energy utilisation. Other differences included a larger number of birds per pen and gender separation, which enabled the comparison of responses between males and females. As was the case in the studies by Marchal et al. (2021), a negative control diet without added Pi was not included as a stand-alone treatment. This was on ethical grounds, as the severe $\mathrm{P}$ deficiency in such a diet [having a non-phytate $\mathrm{P}(\mathrm{nPP})$ content of only $1.4 \mathrm{~g} / \mathrm{kg}$ during starter phase, some $3.4 \mathrm{~g} / \mathrm{kg}$ below than the nPP requirement stated by the breeder for the period d 0 to 10 ( $4.8 \mathrm{~g} / \mathrm{kg}$; Aviagen Inc., 2019a), would have been expected to cause leg weakness among the birds. Indeed, it has already been established that diets that are less P deficient than those in the present study can significantly impair normal bone formation, reduce tibia ash and strength and negatively affect growth performance in broilers (Dersjant-Li et al., 2020a; Li et al., 2015a, 2020; Qian et al., 1996). The lack of a NC was not considered to have compromised the ability of the study design to address its primary aim, which was to determine whether or not a novel consensus 6-phytase variant applied in a graded dosing-strategy by feeding phase could totally replace dietary $\mathrm{Pi}$ in a high-fibre diet containing xylanase as a background enzyme and a graded reduction in PP by phase, in both males and females.

There was some variability in the analysed levels of nutrients in the diets compared with the formulated levels. Such variability can arise due to incomplete feed mixing, sampling errors or variation in actual ingredients compared to standard values. Across phases, analysed Ca levels in both the PC and IPF diets were $~ 30 \%$ higher than formulated levels ( $20 \%$ higher than breeder recommendations (Aviagen Inc., 2019)). This was likely because limestone was used as a carrier for the vitamin-mineral premix and this additional Ca source was not taken account of during diet formulation. It is well recognised that high dietary Ca can negatively affect growth performance in broilers, especially when $P$ is deficient (Amerah et al., 2014; Dersjant-
Li et al., 2018; Li et al., 2015b). Thus, the high Ca level could have had a negative impact on P digestibility and performance in both PC and IPF diets, but especially for PC. However, previous research has shown clearly that, whilst increasing the dietary Ca level reduced performance in diets deficient in $\mathrm{nPP}(2 \mathrm{~g} / \mathrm{kg})$, it did not have this effect when $\mathrm{nPP}$ was adequate $(4 \mathrm{~g} / \mathrm{kg}$; Li et al., 2015b). The calculated values of nPP (analysed total P minus PP) in the $\mathrm{PC}$ diets indicated that they were adequate in AvP supply, for example, calculated nPP was $4.9 \mathrm{~g} / \mathrm{kg} \mathrm{nPP}$ in PC in starter phase, above the breeder requirement of 4.8 $\mathrm{g} / \mathrm{kg}$ (Aviagen Inc., 2019a). Thus, a higher dietary Ca in the PC diet with adequate nPP level was not expected to have impacted negatively on performance in the present study. Final BW and overall (d 0 to 42) FCR values in both PC and IPF treatments were similar to the published breeder performance objectives (Aviagen Inc., 2019b) which did not suggest any overriding negative effects of the higher Ca content on performance.

The addition of PhyG according to the applied dosing strategy to the IPF diets resulted in performance measures that were equivalent to or better than results from birds fed PC, during all growth phases. The improvements above PC were evident in ADG, BW and FCR responses, whilst tibia ash remained equivalent to $P C$, which suggested an 'extraphosphoric' effect of PhyG. This could include beneficial effects of phytase on digestion and/or retention of nutrients other than P, which could have contributed to the improved performance in birds fed the PhyG supplemented diet. A similar effect was observed by Marchal et al. (2021) for $\mathrm{BW}$ and FCR from $\mathrm{d} 0$ to 21 of age, with IPF treatments containing the same phased PhyG dosing strategy in diets with higher PP content during the finisher phase. DersjantLi et al. (2020c) confirmed an extra-phosphoric effect of PhyG at $1000 \mathrm{FTU} / \mathrm{kg}$ in Pi-free broiler diets, citing improvements in the apparent ileal digestibility (AID) of dry matter, nitrogen, gross energy and amino acids in male broilers at 15 days of age.

The performance of birds fed the IPF diet containing phytase was in line with the breeders' performance objectives (Aviagen Inc., 2019b), where final BW of male and female birds were, respectively, $99.3 \%$ and $100.1 \%$ of the performance objective at 41 days of age. The FCR for birds fed IPF was in line with the breeder's objective (99.7 and $100.1 \%$, respectively, for males and females). No evidence of leg weakness was observed during the study. These findings indicated that availability and balance of nutrients in the IPF diet, enhanced by the P-releasing capacity of the phytase, were sufficient to support normal growth performance, the equivalent to those fed the PC diet. At d 35 and 42 of age, BW of birds receiving IPF was higher compared to $\mathrm{PC}$, and during 0 to 35 and 0 to 42 days of age FCR was improved. The calculated EPEF (Aviagen Inc., 2018; Table 4) was higher in birds who received the IPF diet 
compared to $\mathrm{PC}(+4.9 \%)$ for the overall period ( $\mathrm{d} 0$ to 42$)$. This suggested that the phytase was effective at replacing dietary Pi across the whole growth cycle, including in later growth stages when the diets had relatively low PP content (finisher; 2.8 to $2.9 \mathrm{~g} / \mathrm{kg} \mathrm{PP}$ ), which was desirable from a sustainability perspective. This trial extended the findings of the study by Marchal et al. (2021) who reported total Pi-replacement with a higher phytate content in finisher phase $(\geq 3.3 \mathrm{~g} / \mathrm{kg} \mathrm{PP})$.

Bone mineralisation (tibia ash content on a dry matter basis, and tibia dry weight relative to live weight) in birds fed IPF was equivalent to the $\mathrm{PC}$ at all sampling timepoints. This suggested that the phased dosing strategy of the phytase to the IPF diet was effective in releasing enough $P$ from phytate to maintain normal bone mineralisation in each growth phase, and that the diet was $\mathrm{P}$-adequate. Tibia bone ash has previously been validated as an appropriate indirect response of P-release capacity of phytase in previous broiler studies. First, the dose response relationship between AvP in the diet and tibial ash in the absence of phytase was established using graded addition of an inorganic $\mathrm{P}$ source (such as MCP) to a highly P deficient diet. The linear regression slope was then used to estimate the AvP equivalence of the phytase when added at a given dose level to the diet in the same study (Adedokun et al. 2004; Dersjant-Li et al., 2019; Li et al., 2015a). Li et al. (2015a) concluded that tibia ash weight and ash percentage were equally sensitive to dietary non phytate P (nPP) concentration changes at $21 \mathrm{~d}$ of age. Thus, both can be used as response criteria for relative phytase efficacy estimation. In relation to PhyG, a linear relationship between ileal P digestibility and tibia ash has already been established, based on the data reported by Dersjant-Li et al. (2020a), which further supported the use of tibia ash as a good indicator of $\mathrm{P}$ status in broilers when a highly deficient diet was offered.

Other than the absence of added $\mathrm{Pi}$ and presence of supplemental phytase, other differences between the IPF and PC diets that could, in theory, have influenced the response to phytase were the soy hull content and the reduction in dietary $\mathrm{Ca}$ content. Soy hulls were used in both diets as a replacement ingredient to maintain a similar overall ingredient composition and PP level between treatments. The difference in their content was modest $(\sim 10 \mathrm{~g} / \mathrm{kg}$ or $1 \%$ higher in IPF vs PC). Soy hulls inclusion at $>20 \mathrm{~g} / \mathrm{kg}$ can have a positive effect on nutrient digestibility and growth performance (Scapini et al., 2018; Tejeda and Kim, 2020) but levels in the current study were below this and considered unlikely to have improved responses in the IPF vs PC diet. Similarly, any beneficial effect of dietary $\mathrm{Ca}$ reduction in the IPF diet was considered unlikely to have been a major contributor to the observed equivalence or improvements in performance responses in the (phytase supplemented) IPF compared to PC diets. As discussed above, when $\mathrm{P}$ requirements are met, variation in dietary $\mathrm{Ca}$ levels are expected to have less influence on its utilisation $(\mathrm{Li}$ et al., 2015b): In young broilers aged from 7 to $19 \mathrm{~d}$, these authors observed that, in diets containing a low level of nPP $(2 \mathrm{~g} / \mathrm{kg})$ and dietary Ca levels of $6.5,8.0$ and $9.5 \mathrm{~g} / \mathrm{kg}$, BWG was 452, 426 and $367 \mathrm{~g}$, respectively, indicating a significant negative effect of increasing $\mathrm{Ca}$ level on performance. Whereas, in diets containing an adequate level of nPP (4 g/kg), BWG with increasing dietary Ca level was 496, 503 and 506 g, respectively, showing no effect of $\mathrm{Ca}$ ( $\mathrm{Li}$ et al., 2015b). This demonstrated clearly that increasing the dietary Ca level reduced performance in birds fed diets deficient in nPP but not those containing adequate nPP. As the PC was formulated with sufficient nPP in the current study, any effect of Ca level should have been minimal. Total removal of Pi in the IPF diet reduced the digestible P content (compared to PC) substantially, by 3.0, 2.2, 2.0 and $1.8 \mathrm{~g} / \mathrm{kg}$ in starter, grower, finisher 1 and finisher 2 phases, respectively. The $\mathrm{P}$-deficiency in these diets was expected to have been the major factor affecting performance. As tibia ash data were maintained at the same level between IPF and $\mathrm{PC}$ diets, which confirmed that $\mathrm{P}$ requirement was met in the phytase supplemented IPF treatment. The growth performance responses achieved by birds fed the IPF diet supplemented with PhyG were equivalent (or improved) compared to those achieved by the PC, which could be attributed to the $P$ release and extra-phosphoric effect of the phytase.

Based on the feed intake in each phase and the calculated cost of the diets (based on market prices for ingredients in 2020 and inclusive of the costs of the enzymes), total feed costs per kilogram BWG were estimated as $0.416 € / \mathrm{kg}$ BWG for the PC diet and 0.405 $€ / \mathrm{kg}$ BWG for the IPF diet. On this basis, the PhyG supplemented diet represented a significant feed cost saving to producers.

\section{Conclusion}

The novel consensus bacterial 6-phytase variant was effective in facilitating total replacement of inorganic phosphate in broiler diets containing phytate rich ingredients during an entire growth cycle ( 0 to $42 \mathrm{~d}$ of age). The tiered dosing strategy by phase, in combination with a graded reduction in phytate-P content, such that finisher diets were relatively low in phytate-P $(2.8$ to $2.9 \mathrm{~g} / \mathrm{kg})$, maintained or improved broiler growth performance and tibial ash when compared with a nutritionally adequate control diet containing Pi from MCP. Commercial scale studies are needed to validate these findings in a production setting. 


\section{Acknowledgements}

The authors would like to thank Dr Joelle Buck (Newbury, UK) for her assistance with the writing of this manuscript, which was sponsored by Danisco Animal Nutrition \& Health, IFF, The Netherlands, in accordance with Good Publication Practice guidelines.

\section{Conflict of interest}

Y. Dersjant-Li, L. Marchal and A. Bello are employees of Danisco Animal Nutrition \& Health, IFF, the Netherlands.

\section{References}

Adedokun, S.A., Sands, J.S. and Adeola, O., 2004. Determining the equivalent phosphorus released by an Escherichia coli derived phytase in broiler chicks. Canadian Journal of Animal Science 84: 437-444. https://doi.org/10.4141/A03-117

Amerah, A.M., Plumstead, P.W., Barnard, L.P. and Kumar, A., 2014. Effect of calcium level and phytase addition on ileal phytate degradation and amino acid digestibility of broilers fed cornbased diets. Poultry Science 93: 906-915. https://doi.org/10.3382/ ps.2013-03465

Association of Official Analytical Chemists (AOAC), 1990. Official methods of analysis, $15^{\text {th }}$ edition. Washington, DC, USA.

Association of Official Analytical Chemists (AOAC), 2000. Official methods of analysis, $17^{\text {th }}$ edition. Washington, DC, USA.

Aviagen Inc., 2018. Ross broiler pocket guide. Aviagen, Huntsville, AL, USA. Available at: https://en.aviagen.com/assets/Tech_Center/ Ross_Broiler/Ross-Broiler-Pocket-Guide-2020-EN.pdf

Aviagen Inc., 2019a. Ross 308 broiler: nutrition specifications. Aviagen, Huntsville, AL, USA. Available at: https://en.aviagen.com/assets/ Tech_Center/Ross_Broiler/RossBroilerNutritionSpecs2019-EN.pdf Aviagen Inc., 2019b. Ross 308/Ross 308FF performance objectives. Aviagen, Huntsville, AL, USA. Available at: http://eu.aviagen.com/ tech-center/download/1339/Ross308-308FF-BroilerPO2019-EN.pdf

Choct, M. and Annison, G. 1992. Anti-nutritive effect of wheat pentosans in broiler chickens: Roles of viscosity and gut microflora. British Poultry Science 33(4): 821-834. https://doi. org/10.1080/00071669208417524

Christensen, T., Dersjant-Li, Y., Sewalt, V., Mejldal, R., Haaning, S., Pricelius, S., Nikolaev, I., Sorg, R.A. and De Kreij, A., 2020. In vitro characterization of a novel consensus bacterial 6-phytase and one of its variants. Current Biochemical Engineering Journal 6(3): 156-171. https://doi.org/10.2174/2212711906999201020201710

CVB, 2018. CVB feed table 2018. Chemical composition and nutritional values of feedstuffs. Available at: https://www.cvbdiervoeding.nl/ bestand/10501/cvb-feed-table-2018-edition-2.pdf.ashx

Dersjant-Li, Y., Evans, C. and Kumar, A., 2018. Effect of phytase dose and reduction in dietary calcium on performance, nutrient digestibility, bone ash and mineralization in broilers fed cornsoybean meal-based diets with reduced nutrient density. Animal Feed Science and Technology 242: 95-110. https://doi.org/10.1016/j. anifeedsci.2018.05.013
Dersjant-Li, Y., Hruby, M., Evans, C. and Greiner, R., 2019. A critical review of methods used to determine phosphorus and digestible amino acid matrices when using phytase in poultry and pig diets. Journal of Applied Animal Nutrition 7: 1-9. https://doi.org/10.1017/ JAN.2019.1

Dersjant-Li, Y., Archer, G, Stiewert, A.M., Brown, A.A., Sobotik, E.B., Jasek, A., Marchal, L., Bello, A., Sorg, R.A., Christensen, T., Kim, H.-S., Mejldal, R., Nikolaev, I., Pricelius Haaning, S., Sørensen, J.F., De Kreij, A. and Sewalt, V., 2020a. Functionality of a next generation biosynthetic bacterial 6-phytase in enhancing phosphorus availability to broilers fed a corn-soybean meal-based diet. Animal Feed Science and Technology 264: 114481. https:// doi.org/10.1016/j.anifeedsci.2020.114481

Dersjant-Li, Y., Villca, B., Sewalt, V., De Kreij, A., Marchal, L. and Velayudhan, D.E., 2020b. Functionality of a next generation biosynthetic bacterial 6-phytase in enhancing phosphorus availability to weaned piglets fed a corn-soybean meal-based diet without added inorganic phosphate. Animal Nutrition 6: 24-30. https://doi.org/10.1016/j.aninu.2019.11.003

Dersjant-Li, Y., Abdollah, M.R., Waller, K., Bello, A., Marchal, L. and Ravindran, V., 2020c. Effect of a novel consensus bacterial 6-phytase variant on apparent ileal digestibility of amino acids in broilers at 15 days of age. Abstract No. 149. Poultry Science Association 109 th $^{\text {th }}$ Annual Meeting. July 20-22, 2020.

Engelen, A., Van der Heeft., F., Randsdorp, P., Somers, W., Schaefer, J. and Van der Vat, B., 2001. Determination of phytase activity in feed by a colorimetric enzymatic method: collaborative interlaboratory study. Journal of AOAC International 84: 629-633. https://doi. org/10.1093/jaoac/84.3.629

European Council, 2010. Directive 2010/63/EU of the European Parliament and of the council of 22 September 2010 on the protection of animals used for scientific purposes. Official Journal of the EU L 276: 33-79.

Ladics, G.S., Han, K.-H., Jang, M.S., Park, H., Marshall, V., DersjantLi, Y. and Sewalt, V., 2020. Safety evaluation of a novel variant of consensus bacterial phytase. Toxicology Reports 15: 844-851. https://doi.org/10.1016\%2Fj.toxrep.2020.07.004

Lei, X.G., Weaver, D.W., Mullaney, E., Ullah, A.H. and Azain, M.J., 2013. Phytase, a new life for an 'old' enzyme. Annual Review of Animal Biosciences 1: 283-309. https://doi.org/10.1146/annurevanimal-031412-103717

Li, W., Angel, R., Kim, S.-W., Jiménez-Moreno, E., ProszkowiecWeglarz, M. and Plumstead, P.W., 2015a. Impact of response criteria (tibia ash weight vs percent) on phytase relative non phytate phosphorus equivalence. Poultry Science 94: 2228-2234. https:// doi.org/10.3382/ps/pev156

Li, W., Angel, R., Kim, S.-W., Jiménez-Moreno, E., ProszkowiecWeglarz, M. and Plumstead, P.W., 2015b. Age and adaptation to Ca and P deficiencies: 2. Impacts of amino acid digestibility and phytase efficacy in broilers. Poultry Science 94: 2917-2931. https:// dx.doi.org/10.3382/ps/pev273

Li, T., Xing, Shao, Y., Zhang, L., Li, S., Lu, L., Liu, Z., Liao, X. and Luo, X., 2020. Dietary calcium or phosphorus deficiency impairs the bone development by regulating related calcium or phosphorus metabolic utilization parameters of broilers. Poultry Science 99: 3207-3214. https://doi.org/10.1016/j.psj.2020.01.028 
Marchal, L., Dersjant-Li, Y., Bello, A., Sobotik, E.S. and Archer, G., 2021. A novel consensus bacterial 6-phytase variant completely replaced inorganic phosphate in broiler diets, maintaining growth performance and bone quality: data from two independent trials. Poultry Science 100: 100962. https://doi.org/10.1016/j. psj.2020.12.059

Markets and Markets, 2018. Feed phosphates market by type (dicalcium, monocalcium, mono-dicalcium, defluorinated, and tricalcium), livestock (ruminants, swine, poultry, and aquaculture), form (powder and granule), and region - global forecast to 2024. Available at: http://www.marketsandmarkets.com/Market-Reports/ feed-phosphate-market-2507098.html

Pacquette, H.L. and Thompson, J.J., 2018. Minerals and trace elements in milk, milk products, infant formula, and adult/pediatric nutritional formula, ICP-MS method: collaborative study. AOAC Final Action 2015.06, ISO/DIS 21424 IDF 243. Journal of AOAC International 101: 536-561. https://doi.org/10.5740/jaoacint.17-0318

Qian, H., Veit, H.P., Kornegay, E.T., Ravindran V. and Denbow, R.M., 1996. Effects of supplemental phytase and phosphorus on histological and other tibial bone characteristics and performance of broilers fed semi-purified diets. Poultry Science 75: 618-626. https://doi.org/10.3382/ps.0750618

Ribeiro, T.P., Dal Pont, G.C., Dahlke, F., Da Rocha, C., Sorbara, J.O.B. and Maiorka, A., 2019. Available phosphorus and calcium reduction in the finisher phase and phytase utilization on broilers. Journal of Applied Poultry Research 28: 263-270. https://doi.org/10.3382/ japr/pfy066

Romero, L.F., Sands, J.S., Indrakumar, S.E., Plumstead, P.W., Dalsgaard, S. and Ravindran, V., 2014. Contribution of protein, starch, and fat to the apparent ileal digestible energy of corn- and wheat-based broiler diets in response to exogenous xylanase and amylase without or with protease. Poultry Science 93: 2501-2513. https://doi.org/10.3382/ ps.2013-03789
Sacranie, A., Adiya, X., Mydland, L.T. and Svihus, B., 2017. Effect of intermittent feeding and oat hulls to improve phytase efficacy and digestive function in broiler chickens. British Poultry Science 58: 442-451. https://doi.org/10.1080/00071668.2017.1328550

Scapini, L.B., Rorig, A., Ferrarini, A., Fülber, L.M., Canavese, M., Silva, A.M. and Frenandes, J.I.M., 2018. Nutritional evaluation of soybean hulls with or without $\beta$-mannase supplement on performance, intestinal morphometric and carcass yield of broilers chickens. Brazilian Journal of Poultry Science 20(4): 622-642. https://doi. org/10.1590/1806-9061-2017-0581

Scholey, D.V., Morgan, N.K., Riemensperger, A., Hardy, R. and Burton, E.J., 2018. Effect of supplementation of phytase to diets low in inorganic phosphorus on growth performance and mineralization of broilers. Poultry Science 97: 2435-2440. https://doi.org/10.3382/ ps/pey088

Selle, P.H. and Ravindran, V., 2007.Microbial phytase in poultry nutrition. Animal Feed Science and Technology135: 1-41. https:// doi.org/10.1016/j.anifeedsci.2006.06.010

Sharply, A.N., Chapra, S.C., Wedepohl, R., Sims, J.T., Daniel, T.C. and Reddy, K.R., 1994. Managing agricultural phosphorus for protection of surface waters: issues and options. Journal of Environmental Quality 23: 437-451. https://doi.org/10.2134/ jeq1994.00472425002300030006x

Skogland, E., Carlsson, N. and Sandberg, A., 1997. Determination of isomers of inositol mono- to hexaphosphate in selected foods and intestinal contents using high-performance ion chromatography. Journal of Agricultural Food Chemistry 45: 431-436. https://doi. org/10.1021/jf9603238

Tajeda, O.J. and Kim, W.K., 2020. The effects of cellulose and soybean hulls as sources of dietary fiber on the growth performance, organ growth, gut histomorphology, and nutrient digestibility of broiler chickens. Poultry Science 99: 6828-6836. https://doi.org/10.1016/j. psj.2020.08.081 